\title{
A esquistossomose mansônica e a questão da camada do pré-sal
}

\author{
Schistosomiasis mansoni and the subsalt layer
}

Nelson M. G. Caserta*

A gestão e o destino dos recursos calculados como possíveis a partir da exploração da camada do pré-sal e seus derivados tem sido motivo de ampla exposição nos meios de comunicação. Políticos, autoridades, especialistas e até curiosos emitem as mais diferentes projeções. As mais alarmistas veem o Brasil, no futuro, reduzido a um país dependente de um só produto, acomodado a esta riqueza finita, como exemplos hoje conhecidos. As apressadas já enxergam uma cornucópia petrolífera resolvendo todos nossos problemas. E aqui o estado já saiu na frente desejando uma estatal para cuidar de tanta dinheirama a jorrar. Lembra o que popularmente chamamos de "começar a gastar por conta".

O que nós médicos lamentamos é que esta capacidade de planejamento, de vislumbrar aplicações não tenha a mesma energia na área da saúde. A saúde não é tão ou mais estratégica para uma nação? Não merece igual ou maior planejamento e atenção de todos?

Entre as várias questões sanitárias evitáveis que atingem nosso país, algumas são de magnitude alarmante há muitos anos. É o caso da esquistossomose mansônica. Estima-se que esta doença parasitária tenha uma população estimada entre 8 e 18 milhões de indivíduos infectados no Brasil.

Algumas instituições brasileiras e grupos de estudos apresentam linhas de pesquisa e trabalhos que investigam os estágios agressivos desta doença. É a contribuição da nossa comunidade para entender sua ação e ajudar a combatê-la.

Muitas complicações associadas à esquistossomose são relacionadas à fibrose periportal e, em nosso meio, os trabalhos de Santos et al. ${ }^{(1)}$ e Scortegagna et al. ${ }^{(2)}$ estudaram o emprego da ultrassonografia na classifica-

\footnotetext{
* Departamento de Radiologia da Faculdade de Ciências Médicas da Universidade Estadual de Campinas (FCM-Unicamp), Campinas, SP, Brasil. E-mail: ncaser@mpcnet.com.br
}

ção desta fibrose. O método sonográfico pode ser usado de modo confiável nesta classificação e estes estudos brasileiros acrescentaram que a ressonância magnética pode contribuir naquelas situações de discrepância entre a avaliação ultrassonográfica e o quadro clínico de pacientes com esquistossomose mansônica crônica. $\mathrm{Na}$ mesma instituição, duas outras pesquisas trazem mais informações sobre os métodos de imagem nesta doença. Leão et al. ${ }^{(3)}$ confirmaram que a ultrassonografia com Doppler é um método confiável para quantificar o fluxo em pacientes com hipertensão portal de origem esquistossomótica. Esta informação é importante, já que a literatura demonstra resultados controversos em relação à reprodutibilidade do ultrassom Doppler para medir os parâmetros de fluxo nestes pacientes. $\mathrm{O}$ outro estudo, de Gonzalez et al. ${ }^{(4)}$, confirma a utilidade da ultrassonografia na avaliação de nódulos sideróticos esplênicos em pacientes com esquistossomose.

No presente número da Radiologia Brasileira é apresentado um trabalho sobre as alterações das vias biliares na esquistossomose mansônica avaliadas pela colangiorressonância magnética ${ }^{(5)}$. Os autores concluíram que as alterações observadas nas vias biliares foram, em ordem decrescente de ocorrência, distorção da árvore biliar, afilamento, estenose, dilatação e irregularidade. A concordância interobservador para sinais de colangiopatia esquistossomótica pela colangiopancreatografia por ressonância magnética foi quase perfeita para a caracterização de distorção e afilamento da árvore biliar, e substancial para detecção de estenose. Os autores apresentam cuidadosa documentação a partir de sua investigação. Ganc, em tese de doutorado, já exibia, em 1974, excelente demonstração da correlação anatomorradiológica nas alterações das vias biliares em fígados de autópsia ${ }^{(6)}$. São linhas de estudos brasileiras que, assim como outras, reforçam o papel dos 
métodos de imagem na pesquisa de situações graves de nosso próprio meio.

A esquistossomose mansônica representa doença visível à nossa volta, de necessário conhecimento por todos. Se pouco for planejado ou estrategicamente priorizado, continuará a atingir milhões de vidas. Uma realidade concreta, bem diferente do petróleo do pré-sal, que nem sabemos se, quando obtido, ainda manterá valor comercial ou mesmo respeito ambiental.

\section{REFERÊNCIAS}

1. Santos GT, Sales DM, Leão ARS, et al. Reprodutibilidade da classificação ultra-sonográfica de Niamey na avaliação da fibrose periportal na esquistossomose mansônica. Radiol Bras. 2007;40: 377-81.

2. Scortegagna Junior E, Leão ARS, Santos JEM, et al. Avaliação da concordância entre ressonância magnética e ultra-sonografia na classificação da fibrose periportal em esquistossomóticos, segundo a classificação de Niamey. Radiol Bras. 2007;40: 303-8.

3. Leão ARS, Santos JEM, Sales DM, et al. Mensuração do volume de fluxo portal em pacientes esquistossomóticos: avaliação da reprodutibilidade do ultra-som Doppler. Radiol Bras. 2008;41:305-8.

4. Gonzalez TD, Santos JEM, Sales DM, et al. Avaliação ultra-sonográfica de nódulos sideróticos esplênicos em pacientes esquistossomóticos com hipertensão portal. Radiol Bras. 2008; 41:69-73.

5. Sales DM, Santos JEM, Shigueoka DC, et al. Correlação interobservador das alterações morfológicas das vias biliares em pacientes com esquistossomose mansoni pela colangiorressonância magnética. Radiol Bras. 2009;42:277-82.

6. Ganc A. As alterações do sistema bilífero intra-hepático: correlação anátomo-radiológica [tese de doutorado]. São Paulo: Escola Paulista de Medicina; 1974. 